\title{
Discovering simple phenylboronic acid and benzoxaborole derivatives for experimental oncology - phase cycle-specific inducers of apoptosis in A2780 ovarian cancer cells
}

\author{
Mateusz Psurski ${ }^{1}$ (D) Agnieszka Łupicka-Słowik ${ }^{2} \cdot$ Agnieszka Adamczyk-Woźniak $^{3} \cdot$ Joanna Wietrzyk $^{1}$. \\ Andrzej Sporzyński ${ }^{3}$
}

Received: 9 April 2018 / Accepted: 11 May 2018 / Published online: 19 May 2018

(C) The Author(s) 2018

\begin{abstract}
Summary
Objective The aim of the study was to evaluate the antiproliferative potential of simple phenylboronic acid and benzoxaborole derivatives as well as to provide preliminary insight into their mode of action in cancer cells in vitro. Methods The antiproliferative activity was assessed in five diverse cancer cell lines via the SRB method (sulforhodamine B) or MTT (3-(4,5-dimethylthiazol2-yl)-2,5-diphenyltetrazolium bromide) method after $72 \mathrm{~h}$ of treatment. Further studies of the mechanism of action consisted of the influence of the compounds on cell cycle progression and apoptosis induction, which was assessed by flow cytometry, caspase-3 enzymatic activity, fluorescence microscopy and western blot analysis. Results A clear structure-activity relationship was observed for both groups of compounds with several representatives evaluated as highly active antiproliferative agents with low micromolar $\mathrm{IC}_{50}^{72 \mathrm{~h}}$ values. 2-Fluoro-6-formylphenylboronic acid (18) and 3-morpholino-5-fluorobenzoxaborole (27) exhibited strong cell cycle arrest induction in $\mathrm{G}_{2} / \mathrm{M}$ associated with caspase-3 activation in an A2780 ovarian cancer cell line. These events were accompanied by a mitotic catastrophe cell morphology and an increased percentage of aneuploid and tetraploid cells. Further experiments indicated that the compounds were phase cycle-specific agents since cells co-treated with hydroxyurea were less sensitive. The observed cell cycle arrest resulted from significant p21 accumulation and was associated neither with cyclin B1 nor $\beta$-tubulin degradation. Conclusion Phenylboronic acid and benzoxaborole derivatives were found to be highly promising antiproliferative and proapoptotic compounds with a cell cycle-specific mode of action. The presented data support their candidacy for further studies as a novel class of potential anticancer agents.
\end{abstract}

Keywords Phenylboronic acid · Benzoxaborole $\cdot$ Anticancer $\cdot$ Apoptosis $\cdot$ Phase cycle arrest $\cdot$ Ovarian cancer

\section{Introduction}

Boronic acids, which have been known for more than 100 years, have recently gained increasing interest due to their use in organic synthesis, materials' chemistry, supramolecular

Mateusz Psurski

mateusz.psurski@iitd.pan.wroc.pl

Andrzej Sporzyński

spor@ch.pw.edu.pl

1 Hirszfeld Institute of Immunology and Experimental Therapy, Polish Academy of Sciences, 12 Weigla St, 53114 Wrocław, Poland

2 Department of Medicinal Chemistry and Microbiology, Wrocław University of Science and Technology, 29 Wybrzeże Wyspiańskiego St, 50370 Wrocław, Poland

3 Faculty of Chemistry, Warsaw University of Technology, 3 Noakowskiego St, 00664 Warsaw, Poland chemistry, biology and medicine. The ongoing research areas cover both new applications as well as novel classes of compounds. The tetrahedral boron atom geometry in boronic acid closely resembles the enzyme-catalyzed substrate tetrahedral transition state. Thus, the biological activity of boroncontaining compounds is one of the most extensively investigated fields. Since the description of the very first boronic acidderived inhibitor of chymotrypsin [1] in the 1970s, several novel fields of their applications were discovered, including serine protease or histone deacetylase inhibition, and the most successful application - proteasome inhibition by bortezomib [2]. Recently, benzoxaboroles - phenylboronic acids' cyclic internal esters [3] - emerged as a particularly interesting class with tavaborole (21), an antifungal drug already approved by the FDA for humans [4]. Additionally, diboronic acids and their derivatives [5] as well as compounds containing boron clusters [6] are receiving increasing attention. 
The therapeutic potential of boron-containing compounds has been reviewed by Baker et al. [7]. The issues related to boronic compounds in anticancer, antibacterial and antiviral applications have also been reviewed [8] and mentioned in the recent edition of Hall's book on boronic acids [9]. Recently, several reviews concerning the biological activity of organoboron compounds have been published. Yang et al. described a synthetic strategy for the development of new compounds, revealing antibacterial, antifungal, antiparasitic, antiviral, anti-cancer and anti-inflammatory activities [10]. An extensive study published by Mereddy et al. applies to synthetic methods for benzoxaboroles, along with their recent applications in medicinal chemistry [11].

The substantial interest in boron-containing compounds and their potential in medicinal chemistry has mainly focused on antibacterial, antifungal, antiviral or antiprotozoal activity and generally omitted the field of experimental oncology. In addition to alkylboronic acid-derived compounds, represented mainly by proteolytic enzyme inhibitors [2], the influence of boron-containing moiety incorporation into combretastatin A4 [12], cis-stilbenes [13] or chalcones [14] original structure was recently studied. In some cases, such modifications resulted in compounds with improved biological activity [8]. Concurrently, surprisingly little is known about the antiproliferative activity of simple phenylboronic acid (PBA) and benzoxaborole. In the studies by Plopper et al. [15] and Marasovic et al. [16], phenylboronic acid showed limited activity in prostate and mammary gland cancer models. Some benzoxaborole-derived compounds, such as 6aminobenzoxaboroles, exhibited interesting antiproliferative activity [17], whereas some other derivatives such as $\beta$ ketobenzoxaboroles showed no such potential [18]. Herein, for the first time, we provide comprehensive evidence for the high anticancer potential of such compounds using several diverse cancer cell lines that cover a spectrum of malignancies that are currently commonly diagnosed in humans: leukemia (MV-4-11), breast (MCF7), urinary bladder (5637), ovarian (A2780) and lung cancer (A-549). The antiproliferative studies are supplemented with a preliminary analysis of their plausible mechanisms of action of strong cell cycle arrest at the $G_{2} / M$ phase, accompanied by cell death via apoptosis discovered as a major treatment outcome.

\section{Materials and methods}

\section{Chemicals}

The investigated compounds are shown in Fig. 1. Compounds 1, 4 and 6-11 are commercially available. The following compounds have been synthesized by procedures described elsewhere: $\mathbf{2}$ [19], 3 [20], 5 [21], 14 [22], 15-18 [23], 19 [21], 20 [24], 21 [25], 22-23 [24], 24-26 [21]. Compounds 12, 13 and $\mathbf{2 7}$ were synthesized similarly to their analogues $\mathbf{8 , 2}$, and $\mathbf{2 5}$, respectively. The purity of the compounds was checked by ${ }^{1} \mathrm{H}$ and ${ }^{11} \mathrm{~B}$ NMR.

A $50 \mathrm{mM}$ stock solution for each of the tested compounds, as well as for benzyl isothiocyanate (BITC), was prepared in dimethyl sulfoxide (DMSO; Avantor Performance Materials, Gliwice, Poland), and a $500 \mathrm{mM}$ hydroxyurea (HU; SigmaAldrich, Poznań, Poland) stock solution was prepared in miliQ water; all solutions were stored at $-80{ }^{\circ} \mathrm{C}$ as singleuse aliquots. Camptothecin (CPT; Sigma-Aldrich, Poznań, Poland) was stored as a $1 \mathrm{mg} / \mathrm{mL}$ stock solution in DMSO at $-20{ }^{\circ} \mathrm{C}$. Cisplatin (CDDP; Ebewe, Unterach am Attersee, Austria) was maintained as a ready-to-use stock solution $(1 \mathrm{mg} / \mathrm{mL})$ at room temperature.

\section{Cell culture}

The 5637 (urinary bladder transitional cell carcinoma) cell line was purchased from RIKEN BRC (Ibaraki, Japan). The A2780 (ovarian carcinoma), A-549 (non-small lung cancer) and MCF7 (mammary gland carcinoma) cell lines were purchased from the European Collection of Authenticated Cell Cultures (ECACC; Salisbury, UK). The MV-4-11 (biphenotypic B myelomonocytic leukemia) cell line was purchased from the American Type Culture Collection (ATCC; Rockville, USA). All cell lines were tested for mycoplasma contamination using Venor GeM Classic (Minerva Biolabs, Berlin, Germany) with negative results in all cases. All cell lines are maintained at Hirszfeld Institute of Immunology and Experimental Therapy of the Polish Academy of Sciences (HIIET, PAS), Wrocław, Poland. The 5637, A2780 and MV-4-11 cell lines were cultured in RPMI1640 medium w/GlutaMAX ${ }^{\circledR}$ (Thermo Fisher Scientific, Warsaw, Poland) supplemented with $10 \%$ fetal bovine serum (FBS; GE Healthcare HyClone, Logan, USA). The MV-4-11 culture medium was additionally supplemented with $1 \mathrm{mM}$ sodium pyruvate (Sigma-Aldrich, Poznań, Poland). The A549 cell line was cultured in a 1:1 (v/v) mixture of RPMI1640 and Opti-MEM (both HIIET, PAS, Wrocław, Poland) supplemented with $5 \%(v / v)$ FBS and $2 \mathrm{mM} \mathrm{L-glutamine}$ (Sigma-Aldrich, Poznań, Poland). The MCF-7 line was cultured in Eagle's Minimal Essential Medium (EMEM; Thermo Fisher Scientific, Warsaw, Poland) supplemented with $10 \%$ (v/v) FBS, 2 mM L-glutamine, 1\% (v/v) non-essential amino acids, and $8 \mu \mathrm{g} / \mathrm{mL}$ insulin (all Sigma-Aldrich, Poznań, Poland). All culture media contained antibiotics - $100 \mathrm{U} / \mathrm{mL}$ penicillin and $100 \mu \mathrm{g} / \mathrm{mL}$ streptomycin (both PolfaTarchomin, Warsaw, Poland). All cell lines were cultured in a humidified atmosphere at $37^{\circ} \mathrm{C}$ with $5 \% \mathrm{CO}_{2}$ and passaged twice a week using EDTA-Trypsin solution ( $\mathrm{pH} 8$; HIIET, PAS, Wrocław, Poland) as a detachment agent (adherent cell lines only). 


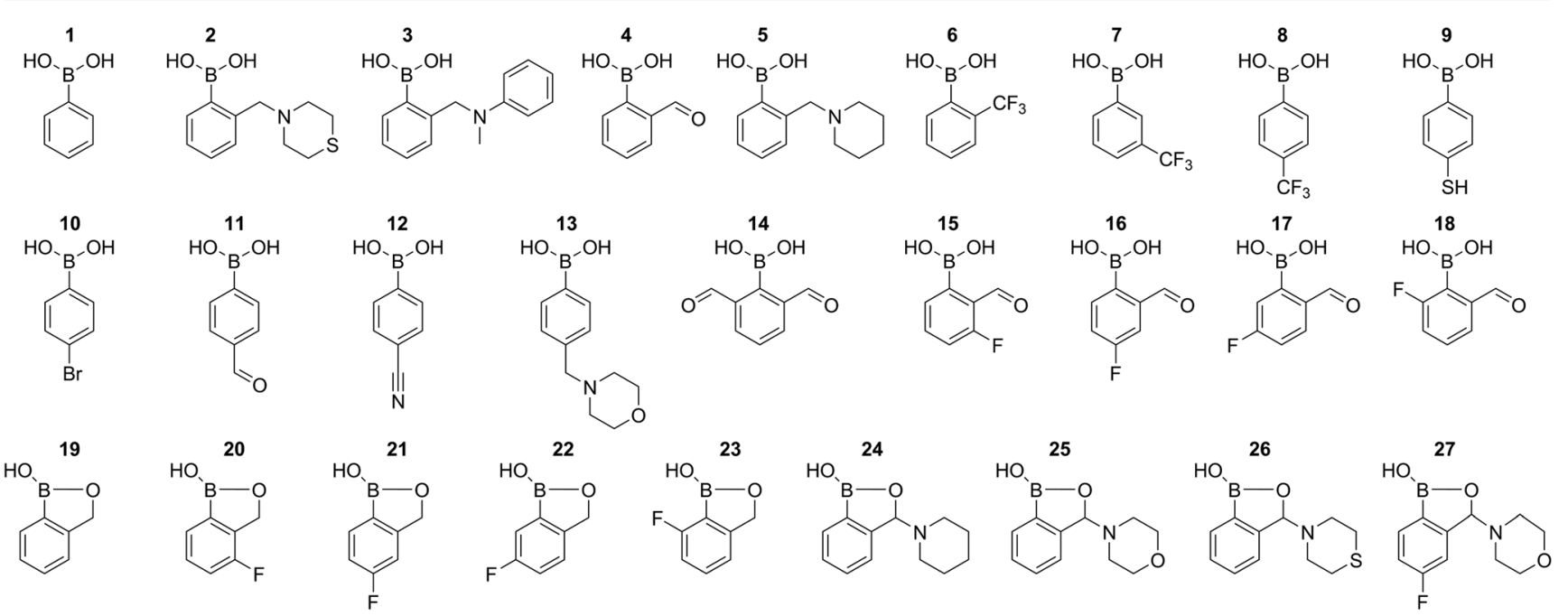

Fig. 1 Chemical structures of the compounds described in the present work

For all 96-well plate-based assays, cells were seeded at a pre-optimized density as follows: $10^{5}$ cells/well for MV-4-11 and A2780, $0.75 \times 10^{5}$ cells/well for MCF7, $0.5 \times 10^{5}$ cells/ well for 5637, and $0.25 \times 10^{5}$ cells/well for A-549 in an appropriate culture medium. For all 24 -well plate-based assays, A2780 cells were seeded at $5 \times 10^{5}$ cells/well density. For western blot sample collection, $10^{6}$ A2780 cells were seeded on 50-mm petri dishes. For experiments utilizing $\mathrm{HU}$, the compound was added $8 \mathrm{~h}$ after cell seeding to obtain a $0.5 \mathrm{mM}$ final concentration. Samples described as a co-treatment $(+)$ were further prepared using a culture medium containing $0.5 \mathrm{mM} \mathrm{HU}$; in samples described as a pretreatment $( \pm)$, after $16 \mathrm{~h}$ of $\mathrm{HU}$ treatment, the culture medium was replaced with a fresh one without HU.

\section{Antiproliferative assay}

At $24 \mathrm{~h}$ after seeding the cells in 96-well plates (Sarstedt, Nümbrecht, Germany), the tested compounds at concentrations ranging from 200 to $5 \mu \mathrm{M}$ or cisplatin $(10-0.01 \mu \mathrm{g} / \mathrm{mL})$ were added. At the desired points in time, the plates were subjected to the SRB assay (according to a previously described protocol [26] with minor modifications [27], adherent cells) or the MTT assay (according to a previously described protocol [28] with minor modifications [27], non-adherent cells), and the absorbance at $540 \mathrm{~nm}$ and $570 \mathrm{~nm}$, respectively, was recorded using a Biotek Hybrid H4 Reader (Biotek Instruments, Bad Friedrichshall, Germany). Compounds at each concentration/time point were tested in triplicate in a single experiment, and each experiment was repeated at least three times independently. The results are presented as the mean cell proliferation inhibition or $\mathrm{IC}_{50}$ (half-maximum inhibitory concentration) \pm standard deviation (SD), which was calculated using the Prolab-3 system based on the Cheburator 0.4 software [29].

\section{Phase cycle analysis}

At $24 \mathrm{~h}$ after seeding the cells in 24-well plates (Sarstedt, Nümbrecht, Germany), the tested compounds were applied at various concentrations. At the desired time points, the cells were trypsinized, fixed with ice-cold $70 \%$ (v/v) ethanol and analyzed for DNA content according to a previously described procedure [27], using a BD LSRFortessa cytometer (BD Bioscience, San Jose, USA). Compounds at each concentration were tested at least three times. The obtained results were analyzed using Flowing Software 2.5.1 (University of Turku, Turku, Finland) and GraphPad Prism 7.03 (GraphPad Software, Inc., La Jolla, USA).

\section{Apoptosis rate assessment by the caspase- 3 activity assay}

At $24 \mathrm{~h}$ after seeding the cells in 24-well plates (Sarstedt, Nümbrecht, Germany), the tested compounds were applied at various concentrations. At the desired time points, the apoptosis rate was analyzed using a previously described procedure [27] with a Biotek Synergy H4 Reader. Camptothecin $(1 \mu \mathrm{g} / \mathrm{mL})$ applied for $4 \mathrm{~h}$ was used as a positive, technical control. Compounds at each concentration were tested at least three times. The obtained results were analyzed using GraphPad Prism 7.03.

\section{Protein level assessment by western blot analysis}

At $24 \mathrm{~h}$ after seeding the cells on $50-\mathrm{mm}$ petri dishes (Sarstedt, Nümbrecht, Germany), the tested compounds were applied at various concentrations. After $48 \mathrm{~h}$ of treatment, the cells were washed with PBS (HIIET, PAS, Wrocław, Poland) and lysed with RIPA Buffer supplemented with protease and phosphatase cocktails (all SigmaAldrich, Poznań, Poland) for $30 \mathrm{~min}$ at $4{ }^{\circ} \mathrm{C}$. After 
centrifuging the samples $\left(15 \mathrm{~min}, 4{ }^{\circ} \mathrm{C}, 15,000 \times \mathrm{g}\right.$; whole cell lysate), the collected supernatant was assessed for protein content using Pierce ${ }^{\mathrm{TM}}$ Coomassie Plus (Thermo Fisher Scientific, Warsaw, Poland) and stored at $-80^{\circ} \mathrm{C}$.

Cell lysates $(25 \mu \mathrm{g}$ of total protein/lane) were resolved by SDS-PAGE (4-12\%, Tris-glycine) under reducing conditions and transferred onto a nitrocellulose membrane (pore size $0.45 \mu \mathrm{m}$; Thermo Fisher Scientific, Warsaw, Poland) using a semi-dry blotting system (Cleaver Scientific, Rugby, UK). The membrane was washed with Tris-buffered saline (TBS, $20 \mathrm{mM}$ Tris-Base, $137 \mathrm{mM} \mathrm{NaCl}$, $\mathrm{pH} 7.6 ; 5 \mathrm{~min}$, room temperature) and blocked with $5 \%$ skim milk in TBS with $0.1 \%$ Tween-20 (TBST) for $1 \mathrm{~h}$ at room temperature. Subsequently, the membrane was washed with TBST ( 5 min, 3 times) and incubated with antigen-specific rabbit IgG antibodies (anti-p21 IgG \#2947, anti-cyclinB1 \#4138, anti- $\beta$-tubulin \#2146; Cell Signaling Technology, Warsaw, Poland) diluted 1:1000 in 5\% BSA in TBST $\left(4{ }^{\circ} \mathrm{C}\right.$, overnight). Next, the membrane was washed with TBST (5 min, 3 times) and incubated with goat anti-rabbit IgG antibodies conjugated to horseradish peroxidase (Sigma-Aldrich, Warsaw, Poland) diluted $1: 1000$ in 5\% BSA in TBST. Following a one-hour incubation at room temperature, the membrane was washed in TBST ( $5 \mathrm{~min}, 3$ times), chemiluminescent peroxidase substrate was added (WestPico, Thermo Fisher Scientific, Warsaw, Poland) and bands were visualized using the blot imaging system (GelLogic 1500, Carestream, Rochester, NY, USA).

Subsequently, the membrane was washed with $10 \mathrm{mM}$ phosphate-buffered saline with $0.05 \%$ Tween (PBST, $\mathrm{pH} 7.4 ; 10 \mathrm{~min}, 3$ times) and incubated with mouse anti- $\beta$ actin IgG antibodies (\#3700; Cell Signaling Technology, Warsaw, Poland) diluted 1:2500 in 0.5\% skim milk in PBST $\left(1 \mathrm{~h}, 37^{\circ} \mathrm{C}\right)$. After washing with PBST (10 min, 3 times), the membrane was incubated with detection HRP-labeled rabbit anti-mouse IgG antibodies (Fitzgerald, Acton, USA) diluted 1:2500 in $0.5 \%$ skim milk in PBST. After a one-hour incubation at $37^{\circ} \mathrm{C}$, the membrane was washed ( $5 \mathrm{~min}, 3$ times) with PBST, and the signal was developed as previously described. The obtained results were analyzed using ImageJ 1.8.0 (www.imagej.nih.gov) and GraphPad Prism 7.03.

\section{Fluorescence microscopy}

At $24 \mathrm{~h}$ after seeding the cells in 96-well plates with blacked walls (Corning, Amsterdam, The Netherlands), the tested compounds were applied at various concentrations. After $48 \mathrm{~h}$ of treatment, the cells were gently washed with PBS, fixed with $4 \%$ paraformaldehyde (Avantor Performance Materials, Gliwice, Poland) in PBS $\left(4{ }^{\circ} \mathrm{C}, 10 \mathrm{~min}\right)$, permeabilized with $0.1 \%$ Triton X-100 (Sigma-Aldrich, Poznań, Poland) in PBS ( $\left.4{ }^{\circ} \mathrm{C}, 15 \mathrm{~min}\right)$, labeled with DyLight ${ }^{\mathrm{TM}} 554$ Phalloidin (\#13054, Cell Signaling Technology, Warsaw,
Poland) for $10 \mathrm{~min}$ and DAPI (Thermo Fisher Scientific, Warsaw, Poland) for $5 \mathrm{~min}$, visualized using an Olympus IX81 fluorescence microscope equipped with a XC10 camera and analyzed with CellSens Dimension software (all Olympus Polska, Warsaw, Poland).

\section{Statistical analysis}

Statistical analyses were performed using GraphPad Prism 7.03. All results are reported as the mean $\pm \mathrm{SD}$. One-way ANOVA analyses with the appropriate post hoc tests described in the figure captions were performed. $p$-values less than 0.05 were considered statistically significant.

\section{Results}

\section{Phenylboronic acids and benzoxaborole derivatives show high antiproliferative activity in selected cancer cell lines}

A series of eighteen phenylboronic acid and nine benzoxaborole structurally diverse derivatives was preliminarily evaluated for antiproliferative activity in five cancer cell lines (Table 1). The activity of the compounds was assessed using the SRB/MTT method after $72 \mathrm{~h}$ of treatment and expressed as the half-maximal inhibitory concentration $\left(\mathrm{IC}_{50}^{72 \mathrm{~h}}\right)$. In the case of compounds for which the $\mathrm{IC}_{50}^{72 \mathrm{~h}}$ exceeded $200 \mu \mathrm{M}$, the mean proliferation inhibition is provided.

Phenylboronic acid (1) was almost completely inactive in all cell lines used, even at concentration as high as $200 \mu \mathrm{M}$. Among all PBA modifications introduced at the 2-position, the formyl moiety (4) was the only group that significantly increased the biological activity. Further studies indicated that the substituent position affected the antiproliferative potential of the compound. For example, the introduction of the formyl group at position " 4 " in $\mathbf{1 1}$ resulted in an $\mathrm{IC}_{50}^{72 \mathrm{~h}}$ rise compared with 4 with the greatest increase observed in the A2780 cell line. Concomitantly, modifications utilizing trifluoromethyl group at various positions $(\mathbf{6}-\mathbf{8})$ revealed the 4-position as the most promising. Further studies applying various moieties indicated that the mercapto group (9) was the most potent enhancer of $\mathbf{1}$ activity among the para-modified derivatives in all cell lines. It should be noted that 9 was the only PBAderived compound that showed at least moderate antiproliferative activity in the MCF7 cell line and was the most active derivative in the A-549 cell line.

Di-substituted derivatives of $\mathbf{1}$ provided further insights into the compound structure-activity relationship and belonged to the most active derivatives tested. In comparison to 4 , a second formyl group introduced at the 2-position (14) did not influence the compound antiproliferative activity or even lowered it 
Table 1 Antiproliferative activity of the tested compounds assessed by the SRB/MTT method after $72 \mathrm{~h}$ of treatment in five diverse cancer cell lines

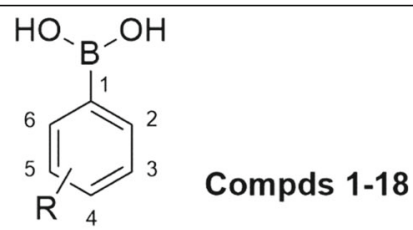<smiles>[R]c1ccc2c(c1)B(O)OC2[R]</smiles>

Compds 19-27

\begin{tabular}{|c|c|c|c|c|c|c|c|c|c|c|c|}
\hline \multirow{3}{*}{$\begin{array}{c}\text { Compd } \\
1\end{array}$} & \multirow{3}{*}{$\begin{array}{l}\mathbf{R} \\
-\end{array}$} & \multicolumn{10}{|c|}{$\mathrm{IC}_{50}^{72 \mathrm{~h}} \pm \mathrm{SD}[\mu \mathrm{M}]$} \\
\hline & & \multicolumn{2}{|c|}{ MV-4-11 } & \multicolumn{2}{|c|}{ MCF7 } & \multicolumn{2}{|c|}{5637} & \multicolumn{2}{|c|}{ A2780 } & \multicolumn{2}{|c|}{ A-549 } \\
\hline & & {$[28.5]^{\mathrm{a}}$} & \pm 4.9 & {$[10.9]^{\mathrm{a}}$} & \pm 0.2 & {$[3.8]^{a}$} & \pm 1.8 & {$[19.2]^{\mathrm{a}}$} & \pm 15.3 & {$[8.6]^{\mathrm{a}}$} & \pm 3.5 \\
\hline 2 & 2-(thiomorpholin-1-ylmethyl) & {$[18.7]^{\mathrm{a}}$} & \pm 1.2 & {$[-3.1]^{a}$} & \pm 4.1 & {$[12.5]^{\mathrm{a}}$} & \pm 5.5 & {$[0.5]^{\mathrm{a}}$} & \pm 6.6 & {$[1.5]^{\mathrm{a}}$} & \pm 1.1 \\
\hline 3 & 2-(N-(N-methylanilino)methyl) & 122.5 & \pm 24.7 & {$[38.7]^{\mathrm{a}}$} & \pm 5.6 & {$[26.6]^{a}$} & \pm 6.0 & 154.3 & \pm 6.8 & 176.8 & \pm 14.7 \\
\hline 4 & 2-CHO & 87.6 & \pm 9.2 & 120.2 & \pm 22.8 & 69.9 & \pm 7.0 & 46.2 & \pm 9.7 & 44.6 & \pm 9.8 \\
\hline 5 & 2-(piperidin-1-ylmethyl) & {$[25.4]^{\mathrm{a}}$} & \pm 0.8 & {$[17.5]^{a}$} & \pm 5.5 & {$[5.2]^{a}$} & \pm 2.0 & {$[6.2]^{\mathrm{a}}$} & \pm 6.1 & {$[4.1]^{\mathrm{a}}$} & \pm 8.5 \\
\hline 6 & $2-\mathrm{CF}_{3}$ & {$[30.7]^{a}$} & \pm 5.3 & {$[15.1]^{\mathrm{a}}$} & \pm 5.9 & {$[11.6]^{a}$} & \pm 0.9 & {$[9.0]^{\mathrm{a}}$} & \pm 9.7 & {$[10.3]^{a}$} & \pm 4.4 \\
\hline 7 & $3-\mathrm{CF}_{3}$ & 122.6 & \pm 23.9 & 166.7 & \pm 47.7 & 118.7 & \pm 3.9 & 102.2 & \pm 9.4 & 185.4 & \pm 7.1 \\
\hline 8 & $4-\mathrm{CF}_{3}$ & 111.7 & \pm 15.4 & 127.4 & \pm 12.4 & 106.3 & \pm 17.1 & 110.1 & \pm 8.0 & 115.0 & \pm 7.8 \\
\hline 9 & 4-SH & 29.7 & \pm 1.8 & 41.6 & \pm 5.5 & 43.3 & \pm 11.9 & 33.0 & \pm 2.7 & 40.0 & \pm 5.3 \\
\hline 10 & $4-B r$ & 115.8 & \pm 2.0 & 202.7 & \pm 3.8 & 160.5 & \pm 30.0 & 123.8 & \pm 19.1 & 163.5 & \pm 11.7 \\
\hline 11 & 4-CHO & 105.0 & \pm 7.2 & 123.2 & \pm 7.4 & 74.8 & \pm 10.0 & 106.9 & \pm 11.8 & 60.5 & \pm 18.0 \\
\hline 12 & 4-CN & {$[26.4]^{\mathrm{a}}$} & \pm 7.9 & {$[33.3]^{\mathrm{a}}$} & \pm 4.0 & {$[22.9]^{a}$} & \pm 6.6 & {$[34.3]^{\mathrm{a}}$} & \pm 7.6 & {$[20.6]^{\mathrm{a}}$} & \pm 4.4 \\
\hline 13 & 4-(morpholin-1-ylmethyl) & 82.3 & \pm 34.4 & 114.4 & \pm 18.3 & 106.8 & \pm 3.6 & 106.9 & \pm 5.6 & 120.9 & \pm 7.5 \\
\hline 14 & 2-CHO, 6-CHO & 87.9 & \pm 8.0 & 127.5 & \pm 6.0 & 93.0 & \pm 8.7 & 49.6 & \pm 2.8 & 175.2 & \pm 1.8 \\
\hline 15 & 2-CHO, 3-F & 42.5 & \pm 9.0 & 131.9 & \pm 28.3 & 86.1 & \pm 16.2 & 20.9 & \pm 3.0 & 79.3 & \pm 11.6 \\
\hline 16 & 2-CHO, 4-F & 40.2 & \pm 7.6 & 85.2 & \pm 20.0 & 37.9 & \pm 13.2 & 14.8 & \pm 1.1 & 52.9 & \pm 12.6 \\
\hline 17 & 2-CHO, 5-F & 84.5 & \pm 14.3 & 165.9 & \pm 12.4 & 124.7 & \pm 7.5 & 113.6 & \pm 20.6 & 122.2 & \pm 22.4 \\
\hline 18 & 2-CHO, 6-F & 22.9 & \pm 5.0 & 101.0 & \pm 30.7 & 27.4 & \pm 7.1 & 11.2 & \pm 0.7 & 64.9 & \pm 9.7 \\
\hline 19 & - & 128.6 & \pm 14.7 & 50.9 & \pm 8.0 & 49.6 & \pm 5.3 & 58.5 & \pm 9.4 & 46.4 & \pm 12.2 \\
\hline 20 & $4-F$ & {$[43.9]^{\mathrm{a}}$} & \pm 3.6 & {$[28.4]^{a}$} & \pm 4.1 & {$[26.6]^{a}$} & \pm 3.1 & {$[39.6]^{a}$} & \pm 10.1 & {$[30.8]^{a}$} & \pm 14.6 \\
\hline 21 & $5-F$ & 92.2 & \pm 5.5 & 35.2 & \pm 3.9 & 30.2 & \pm 1.1 & 41.1 & \pm 8.7 & 25.9 & \pm 3.1 \\
\hline 22 & $6-F$ & 195.8 & \pm 12.9 & 151.9 & \pm 14.7 & {$[42.6]^{a}$} & \pm 8.2 & 173.8 & \pm 51.0 & {$[40.6]^{a}$} & \pm 15.4 \\
\hline 23 & 7-F & {$[36.4]^{a}$} & \pm 9.9 & {$[37.3]^{a}$} & \pm 3.1 & {$[28.0]^{a}$} & \pm 1.7 & {$[34.3]^{\mathrm{a}}$} & \pm 6.9 & {$[25.6]^{a}$} & \pm 8.8 \\
\hline 24 & 3-piperidin & 105.1 & \pm 14.2 & 156.7 & \pm 16.8 & 104.6 & \pm 15.2 & 55.5 & \pm 6.0 & 64.2 & \pm 14.5 \\
\hline 25 & 3-morpholin & 79.4 & \pm 10.5 & 142.4 & \pm 34.6 & 79.9 & \pm 8.5 & 45.6 & \pm 11.2 & 44.3 & \pm 6.4 \\
\hline 26 & 3-thiomorpholin & 74.5 & \pm 20.9 & 150.3 & \pm 24.3 & 81.2 & \pm 19.2 & 48.8 & \pm 6.3 & 51.2 & \pm 9.7 \\
\hline 27 & 3-morpholin, 5-F & 28.9 & \pm 8.6 & 94.1 & \pm 26.3 & 39.4 & \pm 5.1 & 14.8 & \pm 3.2 & 46.4 & \pm 10.7 \\
\hline CDDP & - & 3.2 & \pm 0.9 & 9.0 & \pm 1.3 & 2.5 & \pm 0.5 & 1.0 & \pm 0.4 & 3.4 & \pm 0.6 \\
\hline BITC & - & 1.4 & \pm 0.6 & 8.9 & \pm 2.4 & 5.1 & \pm 1.7 & 3.5 & \pm 0.6 & 8.5 & \pm 1.2 \\
\hline
\end{tabular}

significantly in the A-549 cell line $\left(\mathrm{IC}_{50}^{72 \mathrm{~h}}=44.6\right.$ and $175.2 \mu \mathrm{M}$ for 4 and 14, respectively). Simultaneously, fluorine incorporation provided 2-fluoro-6-formylphenylboronic acid (18), which showed high antiproliferative activity in MV-4-11, 5637 and A2780. Excluding the markedly less sensitive MCF7 and A549 cell lines, 18 was the most active PBA derivative tested. It is worth noting the striking influence of the fluorine position in 15-18. Compound 16 with fluorine at the 4-position had almost equal activity to $\mathbf{1 8}$, whereas $\mathbf{1 5}$ with fluorine at the 3position showed markedly lower activity, especially in 5637 cells ( $\mathrm{IC}_{50}^{72 \mathrm{~h}}$ lower, more than 3 times). Additionally, 17 (fluorine at 5-position) was more than 10 times less active in the A2780 cell line and approximately 4 times less active in MV-4-11 and 5637 in comparison to $\mathbf{1 8 .}$

An even more notable impact of fluorine position on compound antiproliferative activity was observed among benzoxaborole-derived compounds 20-23. Moderate activity of unsubstituted benzoxaborole (19) was abrogated when fluorine was present at the 4-, 6-, and 7-positions (20, 22, and 23 , respectively). However, the presence of that 
substituent at the 5-position (21) resulted in a pronounced rise in activity towards all cell lines, with the highest $\mathrm{IC}_{50}^{72 \mathrm{~h}}$ drop in 5637 and A-549. Additionally, 5-fluorobenzoxaborole (21) was the most active benzoxaborole-based compound tested on the MCF7, 5637 and A-549 cell lines. The benzoxaborole substitution at the 3-position (compounds 24-26) had little (on A2780 and A-549 cell lines) or no effect (on MCF7 and 5637 cell lines). MV-4-11 was the only cell line that responded positively to such modifications. Finally, di-substituted 3-morpholino-5-fluorobenzoxaborole (27) proved to be the most active benzoxaborole-based compound in A2780 and MV-4-11 cell lines. None of the tested compounds showed activity comparable to a widely used cytostatic - cisplatin (CDDP) or an additional reference compound - benzyl isothiocyanate (BITC). However, it should be noted that these reference agents plausibly do not share a common mechanism of action with the tested compounds.

\section{Selected phenylboronic acid and benzoxaborole derivatives induce cell cycle arrest and apoptosis in A2780 ovarian cancer cells}

Further studies focused on the basic mechanism of action of 18 and 27 as the most active representatives of phenylboronic acids and benzoxaboroles, respectively. The A2780 ovarian cancer cell line was used in all subsequent studies because of its high sensitivity to the tested compounds. First, the influence of the compound on the cell cycle was assessed using a standard, RNAse/propidium iodide-based protocol (Fig. 2a, d, e). Treatment of the cells with various compound concentrations for $48 \mathrm{~h}$ significantly modulated cell cycle progression with $\mathrm{G}_{2} / \mathrm{M}$ phase arrest. The 2-fluoro-6formylphenylbronic acid (18) significantly increased the percentage of cells in $\mathrm{G}_{2} / \mathrm{M}$ phase even at the lowest $5 \mu \mathrm{M}$ concentration used $(40.4 \pm 8.8 \%$ in comparison to $21.0 \pm 4.6 \%$ in the Ctrl), with highest increase observed for $10 \mu \mathrm{M}(59.12 \pm$ $6.56 \%$ ). In both cases, the $\mathrm{G}_{2} / \mathrm{M}$ phase arrest was accompanied by a pronounced decrease in $\mathrm{G}_{0} / \mathrm{G}_{1}$ and $\mathrm{S}$ phase cells percentage and significant increase in the percentage of tetraploid cells $(>4 \mathrm{~N})-$ from $0.9 \pm 0.1 \%$ in the control to $15.6 \pm$ $2.8 \%$ in the sample treated with $\mathbf{1 8}$ at a $10 \mu \mathrm{M}$ concentration. Surprisingly, at a high $25 \mu \mathrm{M}$ concentration, the cell cycle progression arrest caused by $\mathbf{1 8}$ shifted towards significant $\mathrm{S}$ phase arrest $(53.9 \pm 6.3 \%$ cells in comparison to $18.9 \pm 2.8 \%$ in the Ctrl) accompanied by almost complete decay of $\mathrm{G}_{0} / \mathrm{G}_{1}$ phase $(6.8 \pm 1.2 \%$ in comparison to $59.2 \pm 6.9 \%$ in the Ctrl). The tetraploid cell population decreased in comparison to the sample treated with $\mathbf{1 8}$ at the $10 \mu \mathrm{M}$ concentration, but they remained significantly higher than in control samples $(5.1 \pm$ $2.8 \%$ in comparison to $0.9 \pm 0.1 \%$ in Ctrl). The 3-morpholin5-fluorobenzoxaborole (27) influenced the cell cycle by significantly increasing the percentage of cells in the $\mathrm{G}_{2} / \mathrm{M}$ phase and the number of tetraploid cells when A2780 cells were treated with $10 \mu \mathrm{M}\left(31.6 \pm 5.2 \%\right.$ cells in $\mathrm{G}_{2} / \mathrm{M}$ phase and $5.4 \pm 2.1 \%$ tetraploid cells $)$ and $25 \mu \mathrm{M}(61.3 \pm 3.7 \%$ cells in
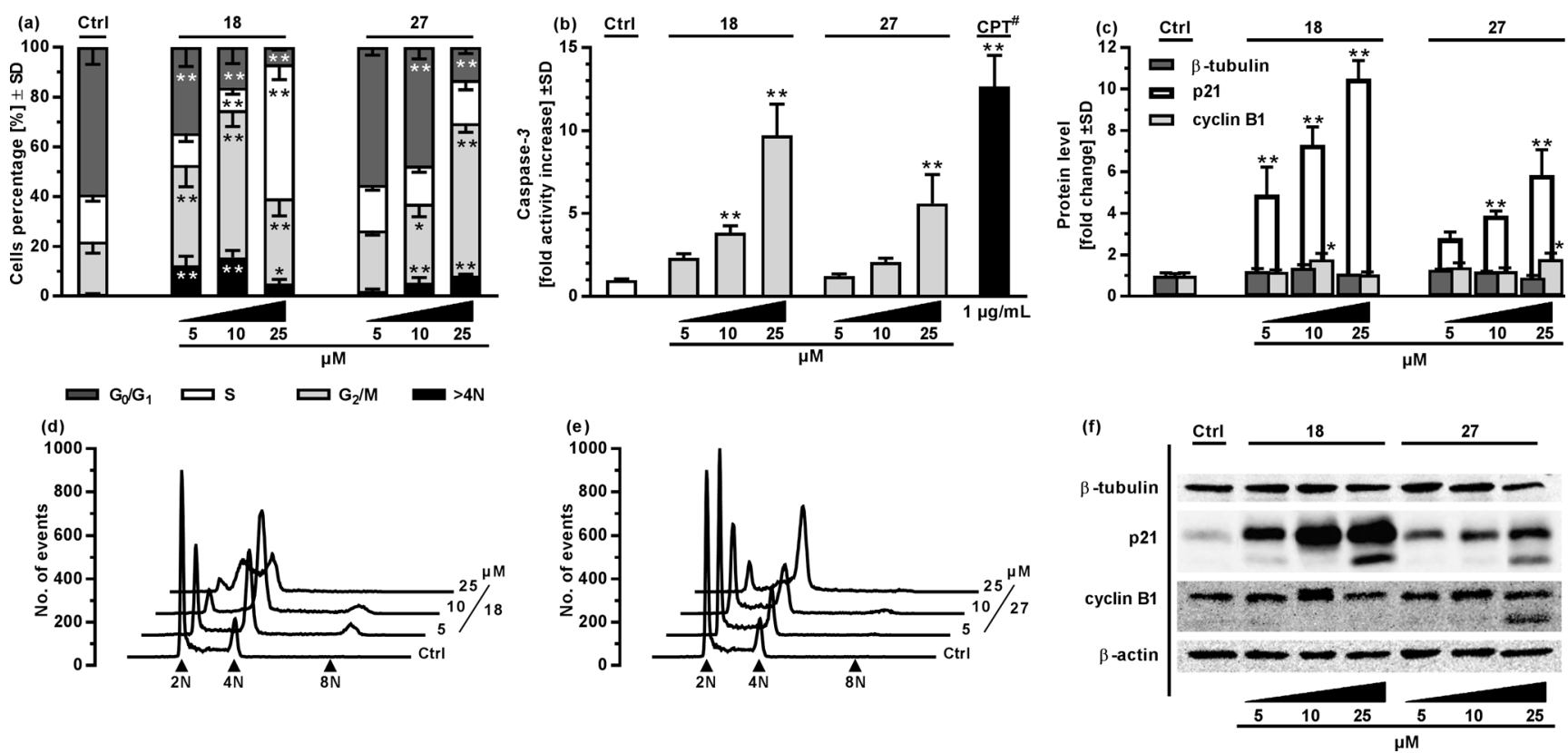

Fig. 2 Basic evaluation of the mechanisms of action of the compounds in A2780 ovarian cancer cells after $48 \mathrm{~h}$ of treatment. a Cell cycle analysis after $48 \mathrm{~h}$ of treatment with $\mathbf{1 8}$ and 27. b Apoptosis rate by caspase-3 activity assessment after $48 \mathrm{~h}$ of treatment with the compounds. " Camptothecin (CPT) was added for $4 \mathrm{~h}$ and served as a positive, technical control. c Western blot analysis of selected protein content in whole cell lysate. d, e
Representative histograms of the cell cycle analysis performed using $\mathbf{1 8}$ (d) and 27 (e). $2 \mathrm{~N}$ stands for cells in $\mathrm{G}_{0} / \mathrm{G}_{1}$ phase, $4 \mathrm{~N}$ stands for cells in $\mathrm{G}_{2} / \mathrm{M}$ phase, $8 \mathrm{~N}$ stands for tetraploid cells. f Representative western blot images. * $-p<0.05, * *-p<0.01$ - one-way ANOVA with Dunnett's multiple comparisons test compared to the $\mathrm{Ctrl}$ 
$\mathrm{G}_{2} / \mathrm{M}$ phase and $8.3 \pm 0.6 \%$ tetraploid cells), but not with $5 \mu \mathrm{M}$. In both cases, the $\mathrm{G}_{2} / \mathrm{M}$ phase arrest was associated with a significant decrease in $\mathrm{G}_{0} / \mathrm{G}_{1}$ cell percentage, with the highest of more than 3.8-times decay in the sample treated with 27 at a concentration of $25 \mu \mathrm{M}(13.2 \pm 2.6 \%$ in comparison to $50.5 \pm 6.9 \%$ in the $\mathrm{Ctrl}$ ).

Subsequently, the pro-apoptotic activity of the compounds was assessed after $48 \mathrm{~h}$ of A2780 cell treatment by caspase-3 enzymatic activity analysis (Fig. 2b). Caspase-3 is an effector enzyme that is activated regardless of the upstream events that caused apoptosis [30]. Such experiments provide insights concerning whether a tested agent is able to induce apoptosis without distinguishing the intra- and extracellular apoptotic pathways. Both compounds exhibited dose-dependent potential as pro-apoptotic agents, with the highest activation observed for the $\mathbf{1 8}$ at $25 \mu \mathrm{M}$ concentration $(9.7 \pm 1.9$ - fold caspase-3 activity increase in comparison to the Ctrl). Similarly to the cell cycle analysis, 27 caused apoptosis of a slightly lower scope, with a 5.6 \pm 1.8 - fold caspase-3 activity increase with $25 \mu \mathrm{M}$.

To provide further insight into the compound mode of action, $\beta$-tubulin, $\mathrm{p} 21$ and cyclin B1 protein levels were assessed by western blot analysis after $48 \mathrm{~h}$ of A2780 cell treatment with various compound concentrations (Fig. 2c, f). These proteins were selected because of their crucial role in microtubule assembly and mitosis ( $\beta$-tubulin) [31], S- $\mathrm{G}_{2}-\mathrm{M}$ cell cycle progression checkpoints (cyclin B1) [32] or as a master inhibitor of cyclin kinases responsible for cell cycle progression control (p21) [32]. A remarkable, dose-dependent increase in p21 level was observed when cells were treated with 18 , even at the highest concentration used $(25 \mu \mathrm{M})$, which caused $\mathrm{S}$, not $\mathrm{G}_{2} /$ $\mathrm{M}$ phase cell cycle arrest. Compound 27 induced a slightly less pronounced increase in the $\mathrm{p} 21$ protein level, but similarly to 18, a clear dose-dependence was demonstrated. Cyclin B1 level was significantly increased when cells were treated with 18 at $10 \mu \mathrm{M}(1.8 \pm 0.3$ - fold level increase $)$ and 27 at $25 \mu \mathrm{M}$ $(1.8 \pm 0.3$ - fold level increase), but its level remained equal to the control sample when $\mathbf{1 8}$ was applied at $25 \mu \mathrm{M}$, which correlates with its ability to suppress cell cycle progression in $\mathrm{S}$ phase. $\beta$-tubulin level did not change significantly as a result of the compound treatment regardless of the concentration used.

\section{A2780 cells treated with phenylboronic acid and benzoxaborole derivatives exhibit a mitotic catastrophe-like morphology}

A clear correlation between cell cycle arrest in $\mathrm{G}_{2} / \mathrm{M}$ phase, the ability to induce formation of the tetraploid cell population, and the ability of compounds to induce apoptosis was observed. This finding indicated that the compound mode of action was associated with mitotic catastrophe processes, characterized by aberrant mitosis, mitotic cell death, and as a result of aberrant mitosis slippage, the presence of aneuploid and tetraploid cells [33]. To address this hypothesis, A2780 cells treated for $48 \mathrm{~h}$ were stained with phalloidin, which binds to and stabilizes F-actin as well as DAPI to label DNA/nucleus, and examined by fluorescence microscopy (Fig. 3). In contrast to healthy, untreated cells, those treated with various compound concentrations demonstrated features characteristic of apoptosis, e.g., cell membrane blebbing, apoptotic bodies, mitotic catastrophelike aberrant mitotic figures and enlarged, multinucleated cells - the result of failed karyo- and/or cytokinesis. Disruption of cell microfilaments was also often observed, especially actin filament decomposition and the presence of regions that were intensely stained by phalloidin.

\section{The antiproliferative and pro-apoptotic activity of the compound is largely a phase cycle-specific feature}

A strong correlation between the compound-induced cell cycle inhibition and apoptosis rate raised the question of whether both events were not only correlated but also dependent. Additionally, the compound $\mathrm{IC}_{50}$ assessment at various time points indicated that prolonged treatment was necessary to reveal the high antiproliferative potential (Fig. $4 \mathrm{a}$ ). The $\mathrm{IC}_{50}$ values dropped significantly between $24 \mathrm{~h}$ and $48 \mathrm{~h}$ treatment (a drop from $99.7 \pm 27.4 \mu \mathrm{M}$ to $13.2 \pm 4.7 \mu \mathrm{M}$ and $145.6 \pm$ $22.3 \mu \mathrm{M}$ to $22.8 \pm 6.1 \mu \mathrm{M}$ for $\mathbf{1 8}$ and $\mathbf{2 7}$, respectively), similarly to the cell cycle specific cytostatic - cisplatin (12.8 \pm $2.7 \mu \mathrm{M}$ to $1.4 \pm 0.2 \mu \mathrm{M}$ for $24 \mathrm{~h}$ and $48 \mathrm{~h}$, respectively) and in contrast to benzyl isothiocyanate (BITC), which had similar $\mathrm{IC}_{50}$ values after 24,48 and $72 \mathrm{~h}$ of treatment $(7.1 \pm 1.4,5.3 \pm$ $0.6,4.5 \pm 2.8 \mu \mathrm{M}$, respectively; Fig. 4a). BITC is characterized by multimodal activity that is not necessarily associated with a specific cell cycle phase [34]. To address the hypothesis that the tested derivatives act as cell cycle specific agents in a subsequent experiments, we used A2780 cells treated with $0.5 \mathrm{mM} \mathrm{HU}$ - a ribonucleotide reductase inhibitor that is commonly used to arrest cell cycle progression in $\mathrm{G}_{0} / \mathrm{G}_{1}$ or early $\mathrm{S}$ phase [35]. Pre-treatment with HU significantly decreased cell growth, whereas the co-treatment almost completely abrogated it (Fig. 4b). Caspase-3 activation assessed under three different conditions (Fig. 4c) showed that continuous treatment with $\mathrm{HU}$ alone caused a significant increase in caspase- 3 activity $(9 \pm 1.7$ - fold change compared with the untreated control), whereas the ability of $\mathbf{1 8}$ and $\mathbf{2 7}$ to induce apoptosis was completely abolished under these conditions since no further increase in caspase- 3 activity was observed $(8.3 \pm 1.0$ and $9 \pm 0.6$ - fold change compared with the untreated control for $\mathbf{1 8}$ and $\mathbf{2 7}$, respectively), irrespectively of the concentration used (representative results shown). Such a negative effect was not observed when $\mathrm{HU}$ co-treated cells were additionally treated with camptothecin $(40 \pm 5.8$ - fold change compared with the 

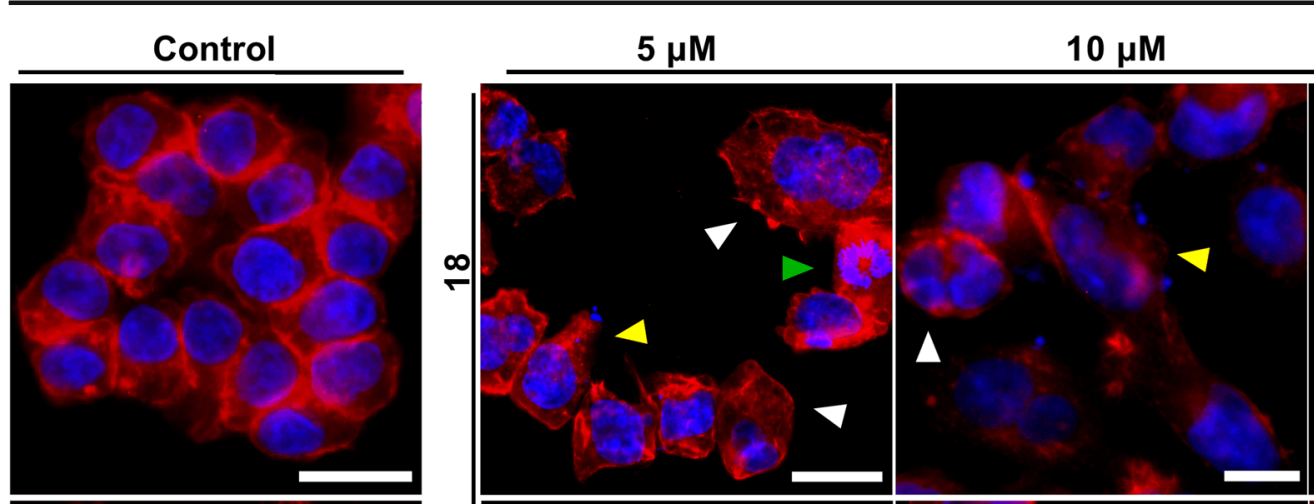

$25 \mu \mathrm{M}$
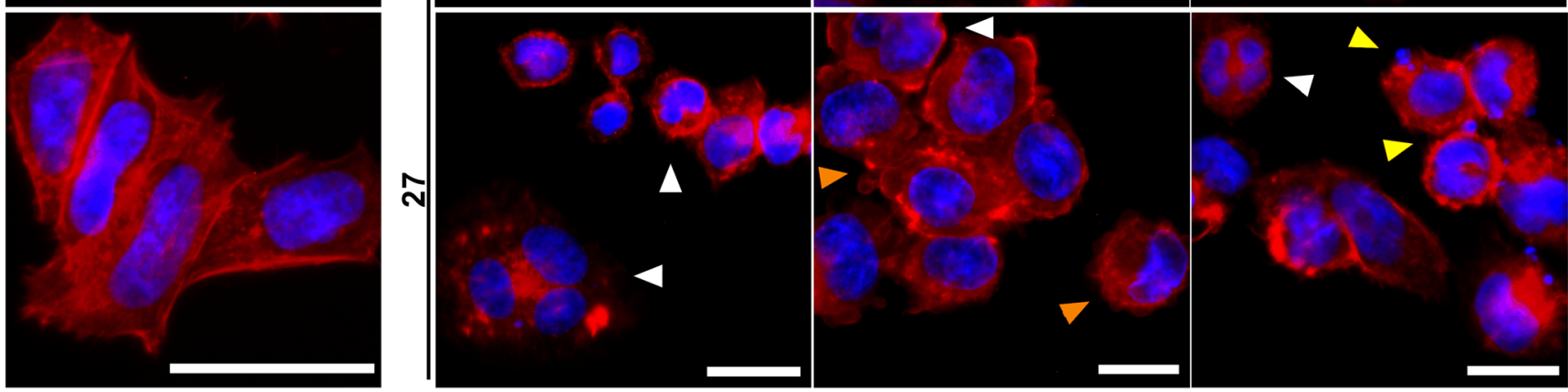

Fig. 3 Representative images obtained by fluorescence microscopy of A2780 ovarian cancer cells treated with various concentrations of $\mathbf{1 8}$ and 27 for $48 \mathrm{~h}$. F-actin was stained with phalloidin tagged with Alexa

(blue). White arrows indicate aberrant, multinucleated cells; green arrows indicate with aberrant mitotic figures; orange arrows indicate cell blebbing; yellow arrows indicate cells undergoing apoptosis or mitotic death. Scale bar $=20 \mu \mathrm{m}$

(a)
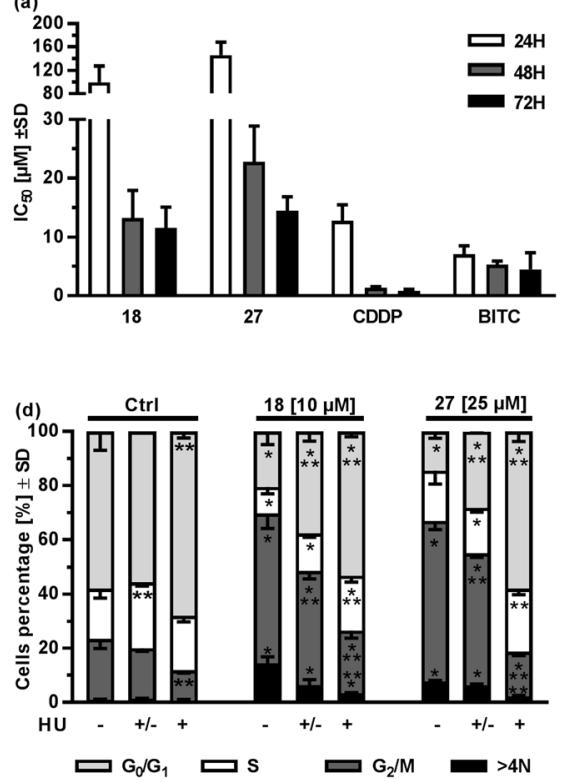

Fig. 4 Evaluation of the cell cycle-dependency of the proapoptotic activity of the compounds. a $\mathrm{IC}_{50}$ calculated after different times of treatment with $\mathbf{1 8}, \mathbf{2 7}$, and reference compounds. b Influence of hydroxyurea treatment on A2780 cell growth. The red parts of the curves indicate the periods when cells were treated with $0.5 \mathrm{mM}$ HU. c The influence of HU on apoptosis induction by the tested compounds used at representative concentrations after $48 \mathrm{~h}$ of treatment. - HU indicates samples that were not treated with $\mathrm{HU}, \pm \mathrm{HU}$ indicates pretreatment, + HU indicates co-treatment (see

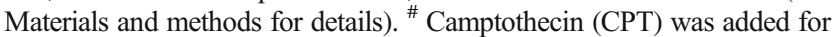
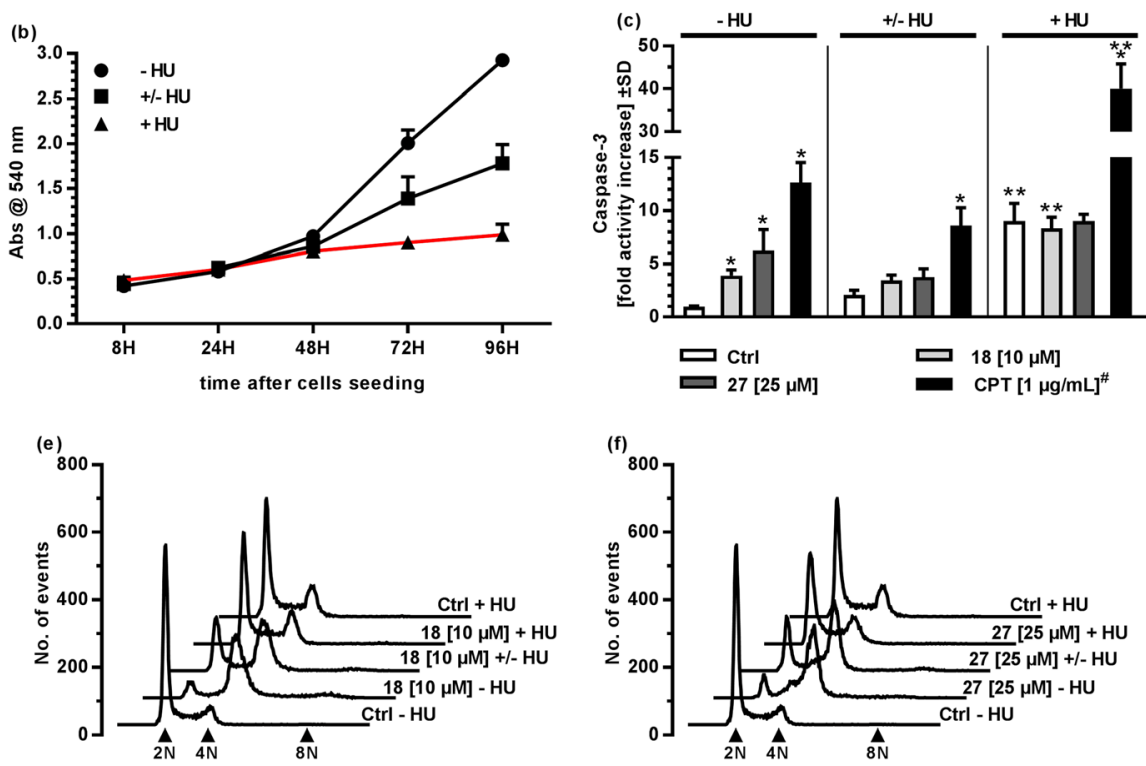

$4 \mathrm{~h}$ and served as a positive, technical control. d Influence of HU on cell cycle arrest induction by the tested compounds used at representative concentrations after $48 \mathrm{~h}$ of treatment. e, f Representative histograms of the cell cycle analysis. $2 \mathrm{~N}$ stands for cells in $\mathrm{G}_{0} / \mathrm{G}_{1}$ phase, $4 \mathrm{~N}$ stands for cells in $\mathrm{G}_{2} / \mathrm{M}$ phase, $8 \mathrm{~N}$ stands for tetraploid cells. $* \mathrm{p}<0.05$ - one-way ANOVA with Dunnett's multiple comparisons test compared to the corresponding Ctrl; ** $\mathrm{p}<0.05$ - one-way ANOVA with Dunnett's multiple comparisons test compared to the corresponding - HU sample 
untreated control). In the samples that were pre-treated with $\mathrm{HU}$, the ability of $\mathbf{1 8}$ and $\mathbf{2 7}$ to induce apoptosis was also significantly reduced. Particularly in the case of 27 at $25 \mu \mathrm{M}$, which caused a $3.8 \pm 0.8$ - fold increase in caspase- 3 activity in HU pre-treated cells $(2.1 \pm 0.4$ - fold change for HU pre-treated control cells) in contrast to $6.2 \pm 2.0$ - fold change in untreated cells.

The cell cycle analysis confirmed the above-mentioned observation (Fig. 4d, e, f). Compounds $\mathbf{1 8}$ and $\mathbf{2 7}$ caused a significant increase in $\mathrm{G}_{2} / \mathrm{M}$ and $>4 \mathrm{~N}$ cell percentage, whereas these effects almost completely disappeared when samples were co-treated with $\mathrm{HU}$ and were significantly reduced when cells were pre-treated with HU. The described correlation was observed regardless of the used concentrations of compounds (representative results are presented). This phenomenon was most striking for $\mathbf{2 7}$, which applied alone at $25 \mu \mathrm{M}$ caused a massive accumulation of cells in $\mathrm{G}_{2} / \mathrm{M}$ phase $(64.4 \pm 1.3 \%$ cell percentage) in comparison to the untreated control (22.6 $\pm 3.5 \%$ cells); however, after concurrent usage with $\mathrm{HU}$, its impact was abolished $\left(16.5 \pm 2.0 \%\right.$ cell percentage in $\left.\mathrm{G}_{2} / \mathrm{M}\right)$. Additionally, HU treatment significantly reduced the capability of the tested compounds to induce tetraploidy, e.g., compared with the $16.8 \pm 2.5 \%>4 \mathrm{~N}$ cell percentage originally observed for 18-treated cells (at $10 \mu \mathrm{M}$ ), only $3.2 \pm 0.3 \%$ cells were observed following co-treatment with $\mathrm{HU}(1.0 \pm 0.1 \%$ cell percentage in untreated control). Taken together, the abovedescribed observations clearly indicate that phenylboronic acid and benzoxaborole derivatives act as $\mathrm{G}_{2} / \mathrm{M}$ phase cycle-specific pro-apoptotic agents.

\section{Discussion}

The first boron-containing anticancer drug was bortezomib a dipeptide boronic acid that was featured as a strong proteasome inhibitor and approved by FDA for multiple myeloma treatment in 2003. Since then, much effort was undertaken to search for novel boron-containing compounds that are useful in medicinal chemistry, resulting in a large set of bioactive molecules at various stages of development (including clinical trials) [6]. In the area of experimental oncology, these efforts were focused mainly on boronic acid derivatives [8] with ixazomib, a second generation proteasome inhibitor that was approved for multiple myeloma in 2015 [36]. Concurrently, the (1) anticancer properties of phenylboronic acid were studied only by the Plopper group $[15,37]$. The authors identified $\mathbf{1}$ as a cell growth and migration inhibitor, but the required compound concentrations to observe a biological effect exceeded $500 \mu \mathrm{M}$ in most cases. Recently, moderate anticancer activity of PBA was described in 4T1 murine mammary gland adenocarcinoma and SCCVII squamous carcinoma but also at high concentrations [16].
In our studies, we demonstrated for the first time that the introduction of simple substituents into $\mathbf{1}$ led to highly active phenylboronic acid-derived compounds such as $\mathbf{9 , 1 6}$ and 18 with low micromolar $\mathrm{IC}_{50}^{72 \mathrm{~h}}$ values in several different types of cancer cells. Clear structure-activity relationships were observed, highlighting a significant influence of the substituent type and position. Markedly higher activity of $\mathbf{9}$ was observed in all cancer cell lines among all para-substituted derivatives, which indicated that resonance or inductive effects might play an important role in this matter since the mercapto group was the only electron donating group tested. Moreover, compound $\mathrm{p} K_{\mathrm{a}}$ modulation appeared to be crucial, at least in the case of the di-substituted compounds 15-18, of which the least active was 17 with a $\mathrm{p} K_{\mathrm{a}}=6.72$; the other compounds exhibiting $\mathrm{p} K_{\mathrm{a}}=5.74,6.42$ and 6.05 (for $\mathbf{1 5}, \mathbf{1 6}$, and $\mathbf{1 8}$, respectively [23]; $\mathrm{p} K_{\mathrm{a}}=8.72$ for $\mathbf{1}$ [38]) were significantly more active.

Notable differences were observed in the sensitivity of the cell lines to the tested compounds, with MCF7 breast cancer cells recognized as generally resistant, and ovarian cancer (A2780) as well as leukemia cells (MV-4-11) identified as the most sensitive. The molecular origin of the observed discrepancies remains unknown but identifies biological activity of the compounds as a result of interactions with specific molecular targets rather than their overall toxicity. Moreover, our studies of HU-treated A2780 cells clearly indicated that the compound activity was focused on proliferating cells, with cells in $\mathrm{S}$ and/or $\mathrm{G}_{2} / \mathrm{M}$ phases identified as those targeted by $\mathbf{1 8}$ and $\mathbf{2 7}$.

Since the discovery of the sugar-binding properties of benzoxaboroles in 2006 [39], this class of compounds has received much attention as a potential antifungal, antibacterial, antiviral, antiprotozoal and even anti-inflammatory agent, with tavaborole (21) already approved for the treatment of onychomycosis as the most spectacular example [3]. This interest largely omitted experimental oncology, with few recently published papers focused on this field. Zhang et al. described a set of interesting, highly active chalcone-benzoxaborole hybrids [14], but further studies are needed to reveal to what extent the observed activity resulted from the introduction of the boron-containing moiety. Suman et al. synthesized a series of 6-aminobenzoxaborole derivatives, of which some showed high antiproliferative activity in pancreatic cancer cells (MIA-PaCa-2) [17], whereas some other examples of 6-aminobenzoxaborole-derived compounds showed no activity in MCF7 at a concentration of $50 \mu \mathrm{M}$ [40], similarly to a set of $\beta$-ketobenzoxaboroles synthesized by Sravan Kumar et al. [18]. In both cases, the described compounds had a much more complex chemical structure than the derivatives reported herein. These results clearly indicate that further development of benzoxaborole-based anticancer agents requires a careful selection and evaluation of simple substituents rather than the introduction of additional, complex moieties. A perfect example of such an approach can 
be the antifungal drug tavaborole (21), a derivative comprising a single fluorine atom as a substituent.

In our studies, we not only observed relatively poor activity of the tested benzoxaboroles in MCF7 but also in some other cancer cell lines (data not shown). Concomitantly, several tested compounds exhibited high antiproliferative activity in A2780 and MV-4-11 cell lines, and, to a lesser extent, the 5637 urinary bladder cell line. Similar to PBA derivatives, the acidity of the compounds appeared to play an important role since $\mathrm{p} K_{\mathrm{a}}$ lowering from 7.39 and 7.42 for $\mathbf{1 9}$ and $\mathbf{2 3}$, respectively, to 6.97 observed for $\mathbf{2 1}$ was accompanied by a significant increase in biological activity. However, $\mathbf{2 0}$ and $\mathbf{2 2}$ showed poor antiproliferative potential despite their even lower $\mathrm{p} K_{\mathrm{a}}$ (6.36 and 6.57 , respectively) [21,24], indicating the presence of at least several factors affecting the structure-activity relationships. Interestingly, we observed similar dependencies on several fungal strains [24], which might suggest the compounds' common molecular target (potentially leucyl-tRNA synthetase) in both cases. Clearly, a much larger set of compounds must be examined in future studies spanning a wider set of cancer cell lines to establish definitive rules responsible for the compound activities. Additionally, future studies focused on the disclosure of molecular features of cell lines determining their sensitivity to phenylboronic acid and benzoxaborole derivatives will be of high importance. Nevertheless, our preliminary evaluation clearly demonstrated extensive capabilities for further improvements of the compound biological activity that should provide a set of agents with sub-micromolar activities suitable for in vivo studies of anticancer activity.

The mode of antiproliferative activity of phenylboronic acids is largely unknown. Inhibition of GTPases by the Rho family in the DU-145 prostate cancer cell line was suggested by McAuley et al. as a plausible mechanism [37]. Additionally, a limited $\mathrm{G}_{2} / \mathrm{M}$ cell cycle arrest was observed for various cell lines, including DU-145 and PC-3 prostate cancer cells after treatment with $\mathbf{1}$ [15]. The antibacterial, antifungal and antiprotozoal activity of benzoxaboroles mainly derives from $\beta$-lactamase, PDE4 nucleotide phosphodiesterase, D, D-carboxypeptidase and leucyl-tRNA synthetase (LeuRS) inhibition [3]. Little is known about the mechanisms of action underlying their antiproliferative potential in cancer cells. Studies by Gao et al. indicated LeuRS as a potential target for $\mathbf{2 1}$ and some of its derivatives in human osteosarcoma (U2OS) and ovarian cancer (SKOV-3) cells. The apoptotic morphology associated with the ambiguous transcriptional activity of the p21 promotor and no significant impact on the cell cycle was reported [41].

In the present work, we performed a preliminary evaluation of the mechanism of action underlying phenylboronic acid and benzoxaborole derivative antiproliferative activity. The two most potent representatives - 2-fluoro-6-formylphenylboronic acid (18) and 3-morpholine-5-fluorobenzoxaborole (27) - and the A2780 ovarian cancer cell line were used. A very evident cell cycle arrest at $\mathrm{G}_{2} / \mathrm{M}$ phase associated with a significantly increased level of $\mathrm{p} 21$ protein probably resulted from the binding of p21 to cyclin B1-CDK1 and its inhibition. p21 acts as a cyclin-dependent kinase inhibitor that binds to various cyclinCDK (cyclin dependent kinase) complexes and regulates cell cycle progression [32]. This process also includes binding to cyclin A-CDK1/CDK2 and the cyclin E-CDK2 complexes responsible for $\mathrm{S}$ phase progression, which explains the ability of 18 to induce $\mathrm{S}$ phase arrest at a concentration of $25 \mu \mathrm{M}$. Such activity could also result from p21 binding to the proliferating cell nuclear antigen (PCNA) that is also responsible for $\mathrm{S}$ phase arrest [42]. This hypothesis requires further studies, but it is supported by our observations that the p27 protein level was not markedly increased (data not shown) in any of the compound-treated samples. p27 is another member of the Cip/ Kip family of cyclin-dependent kinase inhibitors that lacks a PCNA binding domain [42]. The upstream mechanisms responsible for the increase in $\mathrm{p} 21$ as a result of compound treatment remain unknown but will be a subject of our future studies. Since the p21 level is also tightly controlled by proteasomedependent degradation [43], the activity of the tested compounds as its inhibitors as well as a multi-targeted mode of action cannot be excluded.

Another possible mechanism underlying such strong $\mathrm{G}_{2} / \mathrm{M}$ arrest might be tubulin polymerization disruption (a feature of antimitotic agents such as vinblastine or colchicine [44]) or $\alpha$ and $\beta$-tubulin degradation (a feature of isothiocyanates such as benzyl or allyl isothiocyanate [45]); however, our preliminary studies excluded this possibility since the $\beta$-tubulin level was not markedly reduced in cells treated with the tested compounds even at high concentrations (Fig. 2c, f), and we did not observe any influence on the tubulin polymerization process (data not shown). Cyclin B1 level increases during cell progression through $\mathrm{G}_{2}$ phase, reaching a maximal level at prophase of mitotic division, and is associated with cyclin B1 shift to the nucleus and cyclin B1-CDK1 activity. In the samples treated with $\mathbf{1 8}$ and $\mathbf{2 7}$ (at $10 \mu \mathrm{M}$ and $25 \mu \mathrm{M}$, respectively), a significant increase in cyclin B1 was accompanied by a high level of aberrant tetraploid cells - plausibly a result of failed mitotic death that led to mitotic catastrophe slippage and an increased number of multinucleated cells. Such cells are increasingly susceptible to cell death with every cell cycle progression and eventually undergo apoptosis [33].

In conclusion, we identified phenylboronic acid and benzoxaborole derivatives as potent antiproliferative agents acting as cell cycle arrest and apoptosis inducers. Great possibilities for further modifications makes them a promising new class of anticancer agents. Additionally, the tested compounds were evaluated as phase cycle-specific agents with activity focused on proliferating cells in late S/early $\mathrm{G}_{2}$ phases. The upstream events caused by $\mathbf{1 8}$ and $\mathbf{2 7}$ that led to the above discussed image of A2780 cells remain unknown, but based 
on these preliminary studies, establishment of the exact mechanisms of action of phenylboronic acid and benzoxaborole derivatives should be possible in the future. Cell line features responsible for the specificity of the observed compounds will also be an important part of further studies.

Acknowledgements MP thanks Maria Liisova, M. Sc., for technical assistance during the in vitro experiments.

Funding These studies were supported by Wrocław Center of Biotechnology within the Leading National Research Center (KNOW) program for the years 2014-2018 (grant no. 126/2017/KNOW/IITD). AŁ-S acknowledge financial support from Wrocław University of Science and Technology (statute funds no. 0401/0195/17). AA-W and AS acknowledge financial support from Warsaw University of Technology (statute funds no. 504/03504/1020).

\section{Compliance with ethical standards}

Conflict of interest All authors declare no conflicts of interest.

Ethical approval This article does not contain any studies with human participants or animals performed by any of the authors.

Open Access This article is distributed under the terms of the Creative Commons Attribution 4.0 International License (http:// creativecommons.org/licenses/by/4.0/), which permits unrestricted use, distribution, and reproduction in any medium, provided you give appropriate credit to the original author(s) and the source, provide a link to the Creative Commons license, and indicate if changes were made.

\section{References}

1. Lienhard GE, Koehler KA (1971) 2-Phenylethaneboronic acid, a possible transition-state analog for chymotrypsin. Biochemistry 10: 2477-2483. https://doi.org/10.1021/bi00789a008

2. Fu H, Fang H, Sun J, Wang H, Liu A, Sun J, Wu Z (2014) Boronic acidbased enzyme inhibitors: a review of recent progress. Curr Med Chem 21:3271-3280. https://doi.org/10.2174/0929867321666140601200803

3. Adamczyk-Woźniak A, Borys KM, Sporzyński A (2015) Recent developments in the chemistry and biological applications of Benzoxaboroles. Chem Rev 115:5224-5247. https://doi.org/10. $1021 /$ cr500642d

4. Saunders J, Maki K, Koski R, Nybo SE (2017) Tavaborole, Efinaconazole, and Luliconazole: three new Antimycotic agents for the treatment of Dermatophytic fungi. J Pharm Pract 30:621630. https://doi.org/10.1177/0897190016660487

5. Sporzyński A, Adamczyk-Woźniak A (2018) Diboronic acids and their derivatives: new perspectives in sensing and materials' chemistry. In: Wythers MC (ed) Advances in materials science research. Volume 32. Nova Science Publishers, Inc., Hauppauge, New York, USA, pp 201-234

6. Leśnikowski ZJ (2016) Recent developments with boron as a platform for novel drug design. Expert Opin Drug Discovery 11:569 578. https://doi.org/10.1080/17460441.2016.1174687

7. Baker SJ, Ding CZ, Akama T, Zhang Y-K, Hernandez V, Xia Y (2009) Therapeutic potential of boron-containing compounds. Future Med Chem 1:1275-1288. https://doi.org/10.4155/fmc.09.71
8. Trippier PC, McGuigan C (2010) Boronic acids in medicinal chemistry: anticancer, antibacterial and antiviral applications. MedChemComm 1:183-198. https://doi.org/10.1039/c0md00119h

9. Hall DG (2011) Boronic acids: preparation and applications in organic synthesis, medicine and materials (volume 1 and 2), 2nd edn. Wiley-VCH, Weinheim, Germany

10. Yang F, Zhu M, Zhang J, Zhou H (2018) Synthesis of biologically active boron-containing compounds. MedChemComm 9:201-211. https://doi.org/10.1039/C7MD00552K

11. Mereddy GR, Chakradhar A, Rutkoski RM, Jonnalagadda SC (2018) Benzoboroxoles: synthesis and applications in medicinal chemistry. J Organomet Chem. https://doi.org/10.1016/j. jorganchem.2018.03.017

12. Kong Y, Grembecka J, Edler MC, Hamel E, Mooberry SL, Sabat M, Rieger J, Brown ML (2005) Structure-based discovery of a boronic acid bioisostere of combretastatin A-4. Chem Biol 12: 1007-1014. https://doi.org/10.1016/j.chembiol.2005.06.016

13. Nakamura H, Kuroda H, Saito H, Suzuki R, Yamori T, Maruyama K, Haga T (2006) Synthesis and biological evaluation of boronic acid containing cis-stilbenes as apoptotic tubulin polymerization inhibitors. ChemMedChem 1:729-740. https://doi.org/10.1002/ cmdc. 200600068

14. Zhang J, Yang F, Qiao Z, Zhu M, Zhou H (2016) Chalconebenzoxaborole hybrids as novel anticancer agents. Bioorg Med Chem Lett 26:5797-5801. https://doi.org/10.1016/j. bmcl.2016.10.024

15. Bradke TM, Hall C, Carper SW, Plopper GE (2008) Phenylboronic acid selectively inhibits human prostate and breast cancer cell migration and decreases viability. Cell Adhes Migr 2:153-160. https:// doi.org/10.4161/cam.2.3.6484

16. Marasovic M, Ivankovic S, Stojkovic R, Djermic D, Galic B, Milos M (2017) In vitro and in vivo antitumour effects of phenylboronic acid against mouse mammary adenocarcinoma 4T1 and squamous carcinoma SCCVII cells. J Enzyme Inhib Med Chem 32:12991304. https://doi.org/10.1080/14756366.2017.1384823

17. Suman P, Patel BP, Kasibotla AV, Solano LN, Jonnalagadda SC (2015) Synthesis and evaluation of functionalized aminobenzoboroxoles as potential anti-cancer agents. J Organomet Chem 798:125-131. https://doi.org/10.1016/j.jorganchem.2015.06.021

18. Sravan Kumar J, Alam MA, Gurrapu S, Nelson G, Williams M, Corsello MA, Johnson JL, Jonnalagadda SC, Mereddy VR (2013) Synthesis and biological evaluation of novel benzoxaboroles as potential antimicrobial and anticancer agents. J Heterocyclic Chem 50:814-820. https://doi.org/10.1002/jhet.1777

19. Adamczyk-Woźniak A, Brzózka Z, Cyrański MK, FilipowiczSzymańska A, Klimentowska P, Żubrowska A, Żukowski K, Sporzyński A (2008) Ortho-(aminomethyl)phenylboronic acids synthesis, structure and sugar receptor activity. Appl Organomet Chem 22:427-432. https://doi.org/10.1002/aoc.1418

20. Adamczyk-Woźniak A, Fratila RM, Madura ID, Pawełko A, Sporzyński A, Tumanowicz M, Velders AH, Żyła J (2011) Reactivity of 2-formylphenylboronic acid toward secondary aromatic amines in amination-reduction reactions. Tetrahedron Lett 52:6639-6642. https://doi.org/10.1016/j.tetlet.2011.10.008

21. Adamczyk-Woźniak A, Borys KM, Madura ID, Pawełko A, Tomecka E, Żukowski K (2013) Lewis acidity and sugar receptor activity of 3-amino-substituted benzoxaboroles and their orthoaminomethylphenylboronic acid analogues. New J Chem 37:188194. https://doi.org/10.1039/C2NJ40687J

22. Adamczyk-Woźniak A, Ejsmont K, Gierczyk B, Kaczorowska E, Matuszewska A, Schroeder G, Sporzyński A, Zarychta B (2015) Novel 2,6-disubstituted phenylboronic compounds synthesis, crystal structures, solution behaviour and reactivity. J Organomet Chem 788:36-41. https://doi.org/10.1016/j. jorganchem.2015.04.026 
23. Kowalska K, Adamczyk-Woźniak A, Gajowiec P, Gierczyk B, Kaczorowska E, Popenda Ł, Schroeder G, Sikorski A, Sporzyński A (2016) Fluoro-substituted 2-formylphenylboronic acids: structures, properties and tautomeric equilibria. J Fluor Chem 187:1-8. https://doi.org/10.1016/j.jfluchem.2016.05.001

24. Adamczyk-Woźniak A, Cabaj MK, Dominiak PM, Gajowiec P, Gierczyk B, Lipok J, Popenda Ł, Schroeder G, Tomecka E, Urbański P, Wieczorek D, Sporzyński A (2015) The influence of fluorine position on the properties of fluorobenzoxaboroles. Bioorg Chem 60:130-135. https://doi.org/10.1016/j.bioorg.2015.05.004

25. Madura ID, Adamczyk-Woźniak A, Jakubczyk M, Sporzyński A (2011) 5-Fluoro-1,3-dihydro-2,1-benzoxaborol-1-ol. Acta Crystallogr Sect E Struct Reports Online 67:0414-0415. https:// doi.org/10.1107/S1600536811001632

26. Skehan P, Storeng R, Scudiero D, Monks A, McMahon J, Vistica D, Warren JT, Bokesch H, Kenney S, Boyd MR (1990) New colorimetric cytotoxicity assay for anticancer-drug screening. JNCI J Natl Cancer Inst 82:1107-1112. https://doi.org/10.1093/jnci/82.13.1107

27. Psurski M, Janczewski Ł, Świtalska M, Gajda A, Goszczyński TM, Oleksyszyn J, Wietrzyk J, Gajda T (2017) Novel phosphonate analogs of sulforaphane: synthesis, in vitro and in vivo anticancer activity. Eur J Med Chem 132:63-80. https://doi.org/10.1016/j. ejmech.2017.03.028

28. Mosmann T (1983) Rapid colorimetric assay for cellular growth and survival: application to proliferation and cytotoxicity assays. J Immunol Methods 65:55-63. https://doi.org/10.1016/00221759(83)90303-4

29. Nevozhay D (2014) Cheburator software for automatically calculating drug inhibitory concentrations from in vitro screening assays. PLoS One 9:e106186. https://doi.org/10.1371/journal.pone.0106186

30. Li J, Yuan J (2008) Caspases in apoptosis and beyond. Oncogene 27:6194-6206. https://doi.org/10.1038/onc.2008.297

31. Jordan M (2002) Mechanism of action of antitumor drugs that interact with microtubules and tubulin. Curr Med Chem Agents 2:117. https://doi.org/10.2174/1568011023354290

32. Abbas T, Dutta A (2009) P21 in cancer: intricate networks and multiple activities. Nat Rev Cancer 9:400-414. https://doi.org/10. 1038/nrc2657

33. Vitale I, Galluzzi L, Castedo M, Kroemer G (2011) Mitotic catastrophe: a mechanism for avoiding genomic instability. Nat Rev Mol Cell Biol 12:385-392. https://doi.org/10.1038/nrm3115

34. Mi L, di Pasqua AJ, Chung FL (2011) Proteins as binding targets of isothiocyanates in cancer prevention. Carcinogenesis 32:14051413. https://doi.org/10.1093/carcin/bgr111

35. Geng F, Tang L, Li Y, Yang L, Choi K-SS, Kazim AL, Zhang Y (2011) Allyl isothiocyanate arrests cancer cells in mitosis, and mitotic arrest in turn leads to apoptosis via Bcl-2 protein phosphorylation. J Biol Chem 286:32259-32267. https://doi.org/10.1074/jbc.M111.278127

36. Azab AK, Muz B, Ghazarian R, Ou M, Luderer M, Kusdono H (2016) Spotlight on ixazomib: potential in the treatment of multiple myeloma. Drug Des Devel Ther 10:217-226. https://doi.org/10. 2147/DDDT.S93602

37. McAuley EM, Bradke TA, Plopper GE (2011) Phenylboronic acid is a more potent inhibitor than boric acid of key signaling networks involved in cancer cell migration. Cell Adhes Migr 5:382-386. https://doi.org/10.4161/cam.5.5.18162

38. Friedman S, Pace B, Pizer R (1974) Complexation of Phenylboronic acid with lactic acid. Stability constant and reaction kinetics. J Am Chem Soc 96:5381-5384. https://doi.org/10.1021/ ja00824a012

39. Dowlut M, Hall DG (2006) An improved class of sugar-binding boronic acids, soluble and capable of complexing glycosides in neutral water. J Am Chem Soc 128:4226-4227. https://doi.org/10. 1021/ja057798c

40. Alam MA, Arora K, Gurrapu S, Jonnalagadda SK, Nelson GL, Kiprof P, Jonnalagadda SC, Mereddy VR (2016) Synthesis and evaluation of functionalized benzoboroxoles as potential antituberculosis agents. Tetrahedron 72:3795-3801. https://doi.org/10. 1016/j.tet.2016.03.038

41. Gao G, Yao Y, Li K, Mashausi DS, Li D, Negi H, Kamle S, Chen H, Wu Z, Zhou H, Li D (2015) A human leucyl-tRNA synthetase as an anticancer target. Onco Targets Ther 8:2933-2942. https://doi.org/ 10.2147/OTT.S88873

42. Niculescu AB, Chen X, Smeets M, Hengst L, Prives C, Reed SI (1998) Effects of p21(Cip1/Waf1) at both the G1/S and the G2/M cell cycle transitions: $p R b$ is a critical determinant in blocking DNA replication and in preventing endoreduplication. Mol Cell Biol 18:629-643. https://doi.org/10.1128/MCB.18.1. 629

43. Lu Z, Hunter T (2010) Ubiquitylation and proteasomal degradation of the p21Cip1, p27Kip1 and p57Kip2 CDK inhibitors. Cell Cycle 9:2342-2352. https://doi.org/10.4164/cc.9.12.11988

44. Mc Gee MM (2015) Targeting the mitotic catastrophe signaling pathway in Cancer. Mediat Inflamm 2015:1-13. https://doi.org/ $10.1155 / 2015 / 146282$

45. Mi L, Gan N, Cheema A, Dakshanamurthy S, Wang X, Yang DCH, Chung F-L (2009) Cancer preventive isothiocyanates induce selective degradation of cellular alpha- and beta-tubulins by proteasomes. J Biol Chem 284:17039-17051. https://doi.org/10. 1074/jbc.M901789200 